\title{
Overexpression of YbeD in Escherichia coli Enhances Thermotolerance ${ }^{\mathbb{S}}$
}

\author{
Sinyeon Kim, Youngshin Kim, and Sung Ho Yoon* \\ Department of Bioscience and Biotechnology, Konkuk University, Seoul 05029, Republic of Korea
}

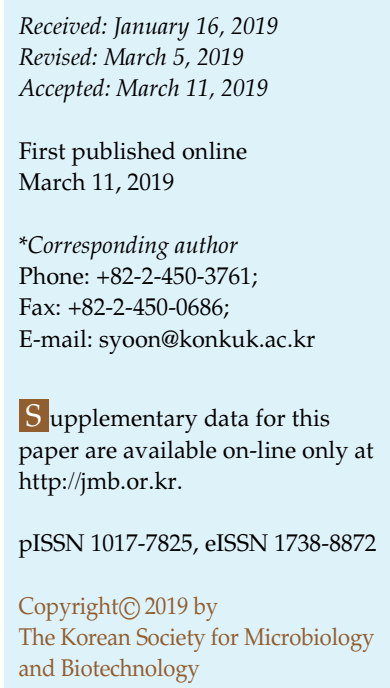

\begin{abstract}
Heat-resistant microbial hosts are required for bioprocess development using high cell density cultivations at the industrial scale. We report that the thermotolerance of Escherichia coli can be enhanced by overexpressing ybeD, which was known to encode a hypothetical protein of unknown function. In the wild-type E. coli BL21(DE3), ybeD transcription level increased over five-fold when temperature was increased from $37^{\circ} \mathrm{C}$ to either $42^{\circ} \mathrm{C}$ or $46^{\circ} \mathrm{C}$. To study the function of $y b e D$, a deletion strain and an overexpression strain were constructed. At $46^{\circ} \mathrm{C}$, in comparison to the wild type, the ybeD-deletion reduced cell growth half-fold, and the $y b e D$ overexpression promoted cell growth over two-fold. The growth enhancement by ybeDoverexpression was much more pronounced at $46^{\circ} \mathrm{C}$ than $37^{\circ} \mathrm{C}$. The $y b e D$-overexpression was also effective in other E. coli strains of MG1655, W3110, DH10B, and BW25113. These findings reveal that $y b e D$ gene plays an important role in enduring high-temperature stress, and that ybe D-overexpression can be a prospective strategy to develop thermotolerant microbial hosts.
\end{abstract}

Keywords: ybeD, Escherichia coli, heat shock protein, thermotolerance

\section{Introduction}

Development of thermotolerant host strains is biotechnologically important as the heat produced during industrial high cell density cultures can heavily reduce the productivity of biomass and recombinant proteins [1-4]. When Escherichia coli cells are exposed to a high temperature, they overexpress heat shock proteins (HSPs) such as chaperones and proteases under the regulation of sigma factor $\sigma^{\mathrm{H}}$ encoded by $r p o H[5,6]$. HSP synthesis confers thermotolerance at high temperatures and, thus, the overexpression of HSPs such as DnaK and GroEL has been commonly employed for recombinant protein production [7, 8]. However, HSP overexpression often results in reduced cell growth and poor quality recombinant protein production [7]. Therefore, it is important to identify new heat shock response genes that can be overexpressed without any negative side effects.

Previously, $28 \sigma^{\mathrm{H}}$-dependent promoter sequences were computationally predicted in the upstream of transcription units that were not previously reported to be related with HSPs [9]. Among them, five genes (yadF, ybeD, glnS, yceJ, and $\operatorname{xer} D$ ) were transcribed either by $\sigma^{\mathrm{H}}$ and $\sigma^{\mathrm{D}}$ in the in vitro transcription assays. Considering that $\sigma^{\mathrm{D}}$ (encoded by predominant sigma factor gene of $r p o D$ ) transcribes most of the growth-related genes during exponential growth, expression of those genes whose expression also can be regulated by $\sigma^{\mathrm{H}}$ might be useful for bacterial growth during high temperatures. Particularly, ybeD was 9.5-fold highly expressed in the transcriptome of E. coli cells overexpressing $\sigma^{\mathrm{H}}$ [9], and showed the highest binding intensity in its promoter region in the genomic SELEX (Systematic evolution of ligands by exponential enrichment) study searching for binding sites of RNAP RpoH holoenzyme [10].

YbeD is a cytoplasmic protein which was determined from computational prediction by PSORT database [11] and from LC-MS/MS analysis of E. coli cytosolic fraction [12]. In E. coli, ybeD encodes a conserved hypothetical protein of unknown function. Protein structure analysis showed that E. coli YbeD had high structural similarity to the ACT domain of D-3-phosphoglycerate dehydrogenase, suggesting its possible role in the allosteric regulation of lipoic acid biosynthesis or the glycine cleavage system [13]. As described above, ybeD belongs to $\sigma^{\mathrm{H}}$ regulon, however, additional and extensive experimental verification for its 
functional role in bacterial growth in high temperature is still required.

E. coli strains, especially BL21(DE3), have been widely used as an industrial host for overproducing various bioproducts using high cell density cultures [14, 15]. In this study, we investigated the usage of $y b e D$ for conferring thermotolerance to E. coli BL21(DE3). We demonstrated that ybeD-overexpression enhanced E. coli growth at $46^{\circ} \mathrm{C}$, while $y b e D$-deletion decreased growth at a high temperature. The effect of $y b e D$-expression on bacterial growth of other E. coli strains (MG1655, W3110, DH10B, and BW25113) were also investigated.

\section{Materials and Methods}

\section{Strains, Plasmids, and Culture Conditions}

E. coli strains and plasmids used in this study are listed in Table 1. E. coli BL21(DE3) was provided by F. William Studier, Brookhaven National Laboratory [16], and was used as a wildtype strain. Cells were grown aerobically in 125-ml flasks containing $25 \mathrm{ml}$ of Luria-Bertani (LB) medium (10 g/1 tryptone, $5 \mathrm{~g} / \mathrm{l}$ yeast extract, and $10 \mathrm{~g} / 1 \mathrm{NaCl}$ ) with shaking at $200 \mathrm{rpm}$. The medium was supplemented with $1 \mathrm{mM}$ L-rhamnose and $77 \mu \mathrm{M}$ chloramphenicol. Cell growth was monitored by measuring absorbance at $600 \mathrm{~nm}\left(\mathrm{OD}_{600}\right)$.

\section{Construction of Gene Deletion and Overexpression Strains}

All primers used in this study are listed in Table S1. The lambda Red recombinase system was used to delete the chromosomal ybeD in E. coli BL21(DE3) through homologous recombination using the linear PCR product as described previously [17]. Briefly, the chloramphenicol resistance $\left(\mathrm{Cm}^{\mathrm{r}}\right)$ cassette was amplified from the plasmid pKD3 using ybeD-del-F/ybeD-del-R primers. The purified PCR product was electroporated into E. coli BL21(DE3) carrying pKD46. The $\mathrm{Cm}^{\mathrm{r}}$ cassette was then removed using pCP20. The deletion was verified by colony PCR and subsequent electrophoresis through a $1.5 \%$ agarose gel, as well as by DNA sequencing.

For ybeD-overexpression, a pAR-ybeD plasmid was constructed by replacing mlacI in pAR-mLacI [18] with ybeD. The pAR-mLacI plasmid contains an L-rhamnose inducible promoter $\left(\mathrm{P}_{\text {rhaBAD }}\right)$ and a chloramphenicol resistance $\left(\mathrm{Cm}^{\mathrm{R}}\right)$ gene. The $y b e D$ was amplified by PCR using genomic DNA of E. coli BL21 (DE3) as the template and ybeD-over-F/ybeD-over-R primers. The pAR-mLacI was digested with NdeI and NarI restriction enzymes to delete mlacI, and then inserted with ybeD. The constructed plasmid (pAR-ybeD) was electroporated into E. coli strains.

\section{Reverse Transcription PCR (RT-PCR) and Quantitative Real- Time PCR (qRT-PCR)}

Total RNA was extracted using the mirVana miRNA Isolation Kit (Thermo Fisher Scientific Inc., USA) as previously described

Table 1. E. coli strains and plasmids used in this study.

\begin{tabular}{|c|c|c|}
\hline Strain or plasmid & Description & Source or reference \\
\hline \multicolumn{3}{|l|}{ Strains } \\
\hline BL21(DE3) & Wild-type & Lab stock \\
\hline BL21(DE3) $\Delta y b e D$ & ybeD null mutant of BL21(DE3) & This study \\
\hline MG1655 & Wild type & Lab stock \\
\hline W3110 & Wild type & КСТС 2223 \\
\hline DH10B & Wild type & КСТС 12020 \\
\hline BW25113 & Wild type & Keio collection [30] \\
\hline JW0014 & BW25113 $\Delta d n a J:: \mathrm{Km}^{\mathrm{r}}$ & Keio collection \\
\hline JW0426 & BW25113 $\Delta$ tig:: $\mathrm{Km}^{\mathrm{r}}$ & Keio collection \\
\hline JW2573 & BW25113 $\Delta c l p B:: \mathrm{Km}^{\mathrm{r}}$ & Keio collection \\
\hline JW0462 & BW25113 $\Delta h t p G:: \mathrm{Km}^{\mathrm{r}}$ & Keio collection \\
\hline JW4103 & BW25113 $\Delta g r o L:: \mathrm{Km}^{\mathrm{r}}$ & Keio collection \\
\hline JW0626 & BW25113 $\Delta y b e D:: \mathrm{Km}^{\mathrm{r}}$ & Keio collection \\
\hline \multicolumn{3}{|l|}{ Plasmids } \\
\hline pACYC184 & Low-copy-number cloning vector $\left(\mathrm{Tet}^{\mathrm{r}} \mathrm{Cm}^{\mathrm{r}}\right)$ (referred to as $\left.\mathrm{CV}\right)$ & NEB \\
\hline pAR & $\begin{array}{l}\text { pACYCDuet-1 derivative with NdeI/Xhol fragment of 1-rhamnose inducible promoter amplified } \\
\text { with primer pair RhamL-F and RhamL-R from E. coli K-12 MG1655 genomic DNA (gDNA) }\end{array}$ & [18] \\
\hline pAR-ybeD & $\begin{array}{l}\text { pAR derivative with NdeI/NarI fragment of wild-type } y b e D \text { amplified with primer pair ybeD-F } \\
\text { and ybeD-R from E. coli BL21(DE3) genomic DNA (referred to as pybeD) }\end{array}$ & This study \\
\hline
\end{tabular}


[19]. The purified RNA $(1 \mu \mathrm{g} / \mathrm{ml})$ was reverse transcribed to cDNA using ReverTra Ace qPCR RT Master Mix with gDNA Remover (Toyobo, Japan). For RT-PCR, the synthesized cDNAs from each sample were amplified using T100 thermal cycler (BioRad, USA). The RT-PCR products were electrophoresed on a $1.5 \%$ agarose gel.

qRT-PCR was performed using the QuantStudio 3 Real-Time PCR System (Applied Biosystems; Thermo Fisher Scientific, Inc., USA). Each qRT-PCR reaction containing $1 \mu \mathrm{l}$ of diluted cDNA, 10 pmol of each primer, and $10 \mu \mathrm{l}$ of iQ SYBR Green Supermix (Bio-Rad, USA) was performed on a 96-well plate for 40 cycles. Relative changes in target gene expression were calculated using the $2^{-\Delta \Delta C_{T}}$ method [20]. The 5S rRNA gene was used as an endogenous control for the normalization of target gene expression. The reference samples $\left(37^{\circ} \mathrm{C}\right)$ were calculated as the $2^{-\Delta \Delta \mathrm{C}_{\mathrm{T}}}$ value of 1 .

\section{SDS-PAGE}

Whole intracellular proteins were electrophoresed using tricineSDS-PAGE (Tricine-sodium dodecyl sulfate-polyacrylamide gel electrophoresis), as described previously [21]. Briefly, cells were collected in reducing sample buffer $(150 \mathrm{mM}$ Tris/ $\mathrm{HCl}, \mathrm{pH} 6.8$, $30 \%$ glycerol, $12 \%$ SDS, $0.1 \%$ bromophenol blue and $6 \%$ mercaptoethanol) and heated for $10 \mathrm{~min}$ at $95^{\circ} \mathrm{C}$ to prepare the whole protein lysates. The samples were separated by electrophoresis in 10\% tricine-SDS-PAGE. The gel was stained with Coomassie blue.

\section{Results and Discussion}

\section{Sequence Analysis of $y b e D$}

In E. coli BL21(DE3), ybeD is 264 bp long, and is located between $d a c A$, encoding D-alanyl-D-alanine carboxypeptidase for peptidoglycan biosynthesis, and $\operatorname{lip} B$, encoding lipoyl (octanoyl) transferase catalyzing the first step of lipoic acid biosynthesis (Fig. 1A) [13]. BLASTN and BLASTP searches of ybeD against the NCBI nonredundant (nr) database did not produce any significant alignments with proteins of known function (E-value $<10$ ), only generating hits to DUF493 family proteins or putative lipoate regulatory proteins. The $y b e D$ homologs were found in all of the 88 finished genomes of $E$. coli strains from BLASTN and BLASTP searches in the Integrated Microbial Genomes with Microbiome Samples (IMG/M) server [22] (Table S2); their amino acid sequences and sizes were exactly the same with those of the queried ybeD of E. coli BL21(DE3). Moreover, at the nucleotide level, the sequence identities were $100 \%$ except for homologs from seven E. coli genomes that had one-nucleotide mismatches. Only one copy of $y b e D$ is present in the E. coli genome; however, E. coli $\mathrm{K}-12$ $\mathrm{DH} 10 \mathrm{~B}$ has two copies of $y b e D$ in a large region precisely duplicated in tandem [23].
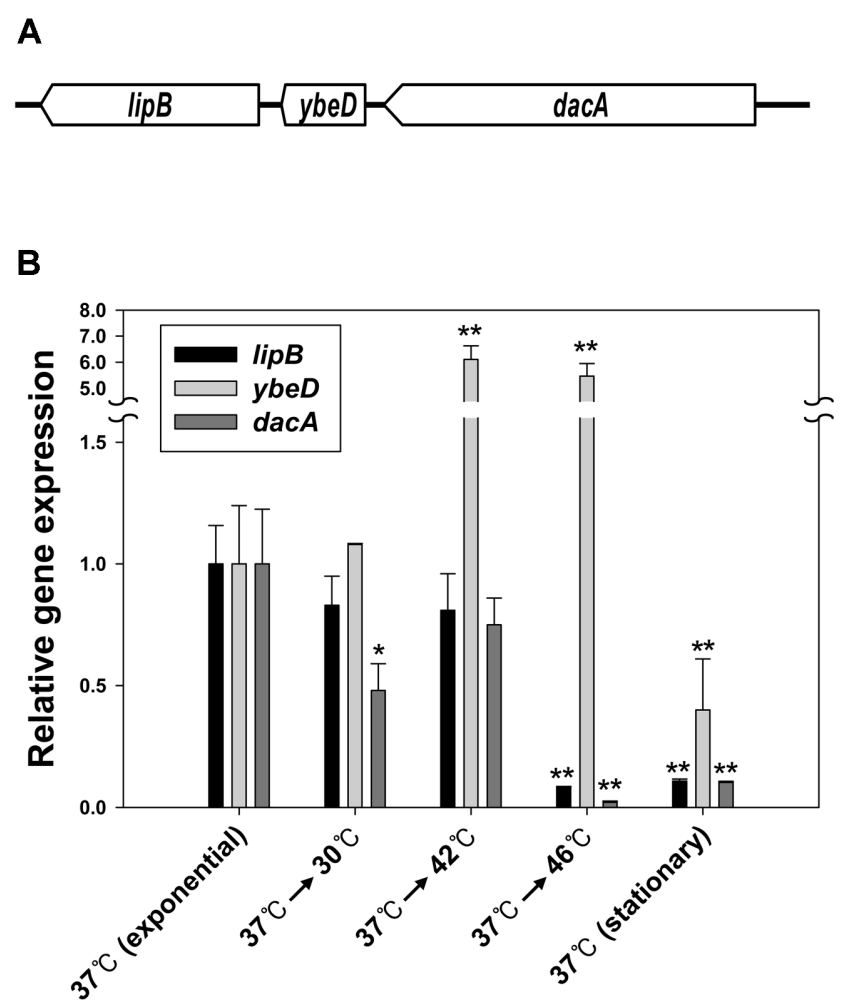

Fig. 1. Relative gene expression of $\operatorname{dac} A, y b e D$, and $\operatorname{lip} B$ in wild-type BL21(DE3) at various temperatures.

(A) Genetic organization of $d a c A, y b e D$, and $\operatorname{lip} B$. (B) Transcription ratio. Wild-type cells growing exponentially at $37^{\circ} \mathrm{C}\left(1.0\right.$ in $\left.\mathrm{OD}_{600}\right)$ were shifted to $30^{\circ} \mathrm{C}, 42^{\circ} \mathrm{C}$, or $46^{\circ} \mathrm{C}$ shaking incubator for $1 \mathrm{~h}$. In addition, the exponentially growing cells were allowed to reach stationary phase at $37^{\circ} \mathrm{C}$. The expression levels of wild-type cells growing exponentially at $37^{\circ} \mathrm{C}$ were set as a relative expression of 1 . The error bar denotes the standard deviation of the mean from four independent qRT-PCR reactions. Asterisks indicate significant difference from the exponential growth at $37^{\circ} \mathrm{C}\left({ }^{*} p\right.$-value $<0.05,{ }^{* *} p$ value $<0.01)$.

\section{Construction of $y b e D$-Deletion and $y b e D$-Overexpression Strains}

We constructed a ybeD-overexpression plasmid (pAR$y b e D$, referred to as $\mathrm{p} y b e D$ hereafter) (Fig. S1), which was transformed into BL21(DE3). We constructed a ybeD null mutant (BL21(DE3) $\Delta y b e D)$ in which only its structural gene was deleted using the lambda Red recombinase system [17]. The deletion was confirmed by RT-PCR analysis of $\triangle y b e D$ exponentially growing at $37^{\circ} \mathrm{C}$ (Fig. S2A). The lipB was found to still be expressed, verifying that the $y b e D$ deletion did not affect lipB expression.

YbeD protein expressions in BL21(DE3), BL21(DE3) $\Delta y b e D$, and BL21(DE3)/pybeD were demonstrated by Coomassie 
blue staining of the 10\% tricine-SDS-PAGE [21] (Fig. S2B). Whole intracellular proteins from an equal amount of cells $\left(1.0\right.$ in $\left.\mathrm{OD}_{600}\right)$ were loaded in each lane of the SDS-PAGE gel and electrophoresed. For each strain, cells growing at $37^{\circ} \mathrm{C}$ were compared between cultures before and after the addition of $1 \mathrm{mM}$ rhamnose. On the gel, YbeD migrated at $\sim 14 \mathrm{kDa}$, a value which is approximately the molecular mass previously estimated by gel filtration ( 13 kDa) [13]. The gel image showed that a large amount of YbeD was expressed only when rhamnose was added to the cultures of ybeD-overexpressing strains (WT/pybeD and $\triangle y b e D / p y b e D)$.

Overexpression and deletion of a gene often causes a toxic effect, resulting in morphological changes such as filamentation [24, 25]. To know whether ybeD expression influences the cell morphology, E. coli cells with overexpression and deletion of $y b e D$ were cultured overnight in LB medium at $37^{\circ} \mathrm{C}$ and $46^{\circ} \mathrm{C}$, and were observed under microscope (Fig. S3). Compared to wild-type BL21(DE3), no obvious differences in cell morphology were found for $y b e D$-deletion and $y b e D$-overexpression strains. The microscopic observation indicates that neither deletion nor overexpression of $y b e D$ have any effect on cell morphology under normal and heat shock conditions.

It should be mentioned that we deliberately used LB complex medium rather than minimal medium [26]. Growth ability of E. coli strains at high temperatures varies with growth medium [26]. It is well known that when E. coli cells grown in minimal medium are transferred to high temperatures, intracellular methionine concentration becomes limited, resulting in cessation of cell growth [27]. The methionine deficiency is mainly caused by temperature sensitivity of the homoserine trans-succinylase catalyzing the first step in the methionine biosynthetic pathway [28]. In our preliminary experiment, BL21(DE3) cultured in glucose-containing M9 minimal medium grew at only up to $42^{\circ} \mathrm{C}$ of mild heat shock condition, primarily due to inactivation of the methionine biosynthetic enzyme. Thus, in the present study, LB rich medium was used to avoid growth defect caused by biosynthetic insufficiency and to investigate temperature-dependent growth control by $y b e D$ expression at the severe heat shock temperature of $46^{\circ} \mathrm{C}$.

\section{Temperature-Dependent Expression of $y b e D$}

Previously, ybeD and lipB were highly expressed in E. coli overexpressing $r p o H$, and were suggested to be $\sigma^{\mathrm{H}}$ regulon members [9]. Thus, it is logical to expect that ybeD expression varies in a temperature-dependent manner. To address this, we measured the mRNA levels of lipB, ybeD, and $d a c A$ at different temperatures by qRT-PCR. E. coli cells growing exponentially at $37^{\circ} \mathrm{C}\left(1.0\right.$ in $\left.\mathrm{OD}_{600}\right)$ were shifted to shaking incubators set at $30^{\circ} \mathrm{C}, 42^{\circ} \mathrm{C}$, or $46^{\circ} \mathrm{C}$. At $37^{\circ} \mathrm{C}$, the cells reached the final density of 4.93 in $\mathrm{OD}_{600}$. Culture temperature shifts from $37^{\circ} \mathrm{C}$ to $30^{\circ} \mathrm{C}, 42^{\circ} \mathrm{C}$, or $46^{\circ} \mathrm{C}$ decreased cell growth to give final cell densities of 4.3, 4.4, and 2.3 in $\mathrm{OD}_{600}$, respectively.

Wild-type cells growing for $1 \mathrm{~h}$ after the temperature shifts were subjected to transcriptional analysis (Fig. 1B). Compared to wild-type BL21(DE3) growing exponentially at $37^{\circ} \mathrm{C}$, the relative expression levels of $d a c A, y b e D$, and lipB were determined by qRT-PCR. This analysis observed that $y b e D$ expression levels had increased significantly $(>5$ fold, $p$-value $<6 \times 10^{-5}$ ) during temperature upshifts from $37^{\circ} \mathrm{C}$ to either $42^{\circ} \mathrm{C}$ or $46^{\circ} \mathrm{C}$; however, little change was observed upon temperature downshift from $37^{\circ} \mathrm{C}$ to $30^{\circ} \mathrm{C}$. The expression pattern of $y b e D$ suggested that $y b e D$ encodes a heat-responsive protein. The expression patterns of $\operatorname{dac} A$ and $\operatorname{lip} B$ were similar: they decreased marginally when temperature change was mild (from $37^{\circ} \mathrm{C}$ to either $30^{\circ} \mathrm{C}$ or $\left.42^{\circ} \mathrm{C}\right)$, and decreased significantly $(<0.1$-fold, $p$ value $<5 \times 10^{-4}$ ) upon severe heat stress (from $37^{\circ} \mathrm{C}$ to $46^{\circ} \mathrm{C}$ ). Moreover, their expression levels were considerably reduced in stationary growth at $37^{\circ} \mathrm{C}$. Considering that

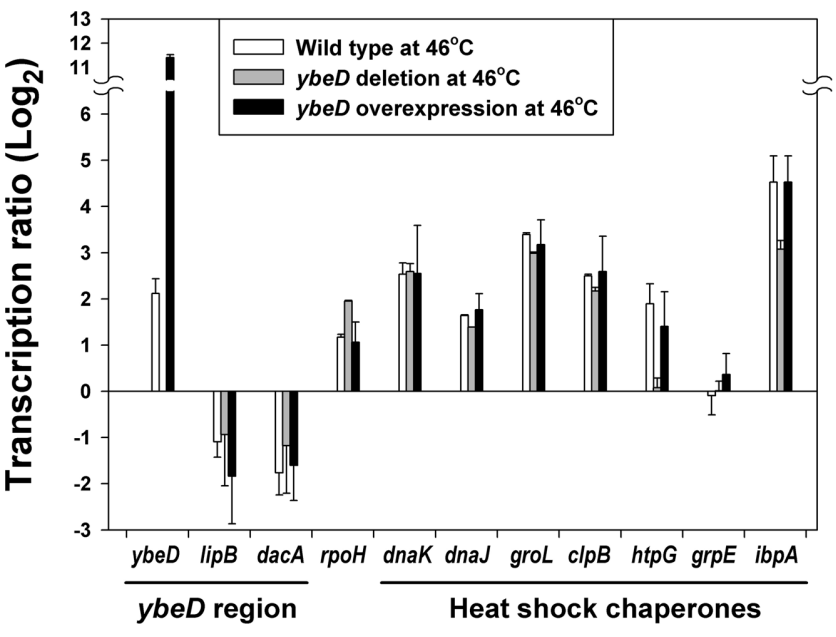

Fig. 2. Relative gene expression of heat shock chaperone genes of wild type, ybeD-deletion, and ybeD-overexpression strains at $46^{\circ} \mathrm{C}$.

BL21(DE3) strains growing exponentially at $37^{\circ} \mathrm{C}\left(1.0\right.$ in $\left.\mathrm{OD}_{600}\right)$ were shifted to $46^{\circ} \mathrm{C}$ shaking incubator for $1 \mathrm{~h}$. The qRT-PCR analyses were performed for strains of wild type (WT/CV, denoted as white bars), $y b e D$-deletion $(\triangle y b e D / C V$, gray bar), and $y b e D$-overexpression $(\Delta y b e D / p y b e D$, black bars). Log2-transformed gene expressions are given as relative values to those from WT exponentially growing at $37^{\circ} \mathrm{C}$. The error bar denotes the standard error of the mean from three biological replications of the qRT-PCR. 
$d a c A$ is involved in peptidoglycan biosynthesis and $\operatorname{lip} B$ is implicated in biosynthesis of lipoic acid, which is used as a cofactor for central metabolic pathways [29], the gene expression levels of $d a c A$ and $\operatorname{lip} B$ seemed to vary in a growth stage-dependent manner.

We were intrigued by the remarkable increase in $y b e D$ transcription of the wild-type cells during temperature upshift from $37^{\circ} \mathrm{C}$ to $46^{\circ} \mathrm{C}$ (Fig. 1B). Next, we investigated the effect of $y b e D$ expression on the expression of heat shock genes (Fig. 2). qRT-PCR analysis was performed on total RNA isolated from wild-type (WT) BL21(DE3) transformed with the empty plasmid (pACYC184, referred to as $\mathrm{CV}$ hereafter), ybeD-deletion strain harboring $\mathrm{CV}$ $(\Delta y b e D / C V)$, and $y b e D$-overexpressing strain $(\Delta y b e D / p y b e D)$. Those cells growing for $1 \mathrm{~h}$ after temperature upshift from $37^{\circ} \mathrm{C}$ to $46^{\circ} \mathrm{C}$ were subjected to transcription analyses of the heat-inducible sigma factor gene $(r p o H)$ and heat shock chaperone genes (dnaK, dnaJ, groL, clpB, htpG, grpE, and $i b p A)$. As compared to case of the wild type at $37^{\circ} \mathrm{C}$, expressions of the heat shock chaperone genes, except grpE, were highly increased in the wild type and ybeD-deletion/ overexpression strains at $46^{\circ} \mathrm{C}$. The increased expression levels of the chaperone genes were similar among the strains, except for no increased $h t p G$ expression in $\Delta y b e D$. This observation raises a question about whether YbeD is a functionally redundant heat shock protein or whether it acts in alternative ways, which requires the omics-based systems approach.

\section{Enhanced Cell Growth at High Temperature by ybeD Overexpression}

Next, we tested the effect of ybeD-overexpression on bacterial growth at a high temperature. Growth of ybeDoverexpressing strain (BL21(DE3)/pybeD) was monitored at temperatures of optimal growth $\left(37^{\circ} \mathrm{C}\right)$ and of severe heat shock $\left(46^{\circ} \mathrm{C}\right)$, and were compared with those of the wild-type (BL21(DE3)/CV) and its ybeD deletion mutant $(\Delta y b e D / C V)$ (Fig. 3A). At $37^{\circ} \mathrm{C}$, the growth behaviors were similar between wild type and ybeD-overexpressing strains, while the ybeD-deletion strain exhibited slow cell growth and lower final cell density; however, the decreases were minimal. At $46^{\circ} \mathrm{C}$, cell growth was highest in ybeD-
A
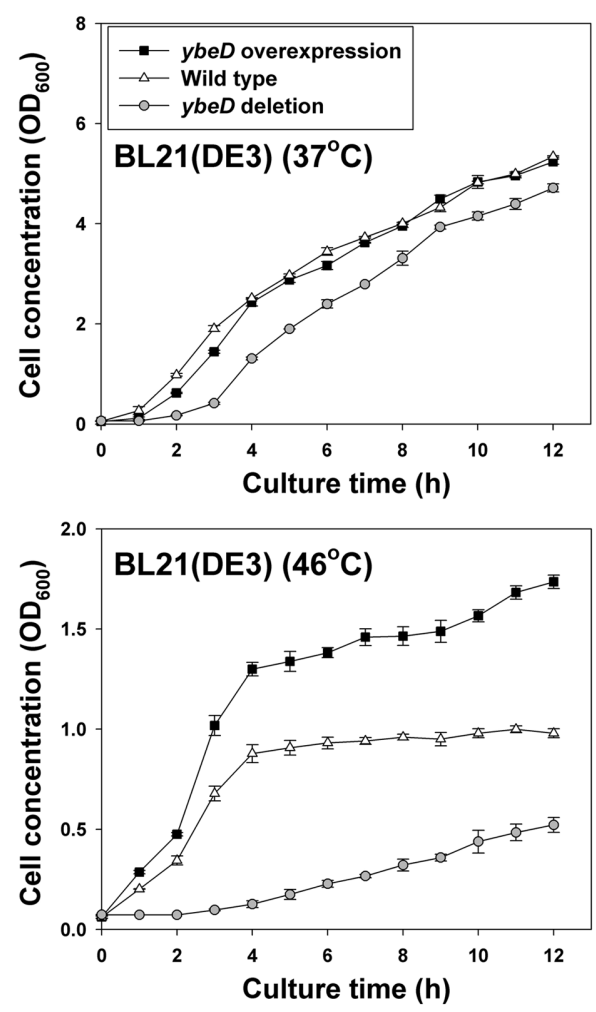

B
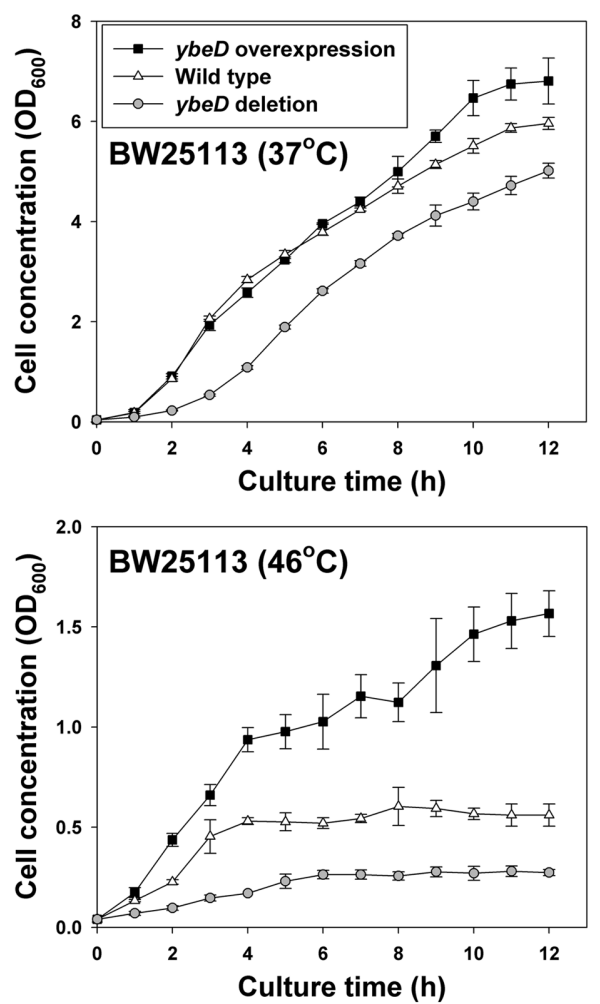

Fig. 3. Growth curves of ybeD-deletion/overexpression strains cultured at $37^{\circ} \mathrm{C}$ and $46^{\circ} \mathrm{C}$.

Wild-type E. coli strains are (A) BL21(DE3) and (B) BW25113. Strains are wild type (WT/CV, denoted as $\triangle$ ), ybeD-overexpression (WT/pybeD,

-), and $y b e D$-deletion $(\triangle y b e D / C V, O)$. The error bar denotes the standard deviation of the mean from three independent cultivations. 
overexpressing strain (ybeD-overexpression $\left(1.8\right.$ in $\left.\mathrm{OD}_{600}\right)>$ wild type (1.0) > ybeD-deletion (0.45)). The growth comparison indicates that $y b e D$-overexpression contributed to the acquired thermotolerance.

To generalize ybeD-overexpression responsible for thermotolerance in E. coli, growth experiments were performed with the other four E. coli strains of BW25113, MG1655, W3110, and DH10B. We obtained BW25113 and BW25113 $\Delta y b e D$ from Keio collection [30], and constructed a ybeD-overexpressing BW25113 (BW25113/pybeD). Their growth patterns at $37^{\circ} \mathrm{C}$ and $46^{\circ} \mathrm{C}$ were similar to the case of BL21(DE3) strains, and the final cell density in BW25113/pybeD was 2.8-fold and 5.7-fold higher than those in BW25113 and BW25113 $\Delta y b e D$, respectively (Fig. 3B). As for MG1655, W3110, and DH10B, each wild-type strain $(\mathrm{WT} / \mathrm{CV})$ and its $y b e D$-overexpressing strain $(\mathrm{WT} / \mathrm{pybeD})$ were cultured at $37^{\circ} \mathrm{C}$ and $46^{\circ} \mathrm{C}$ (Fig. S4). Overnight cultures of WT/pybeD at $46^{\circ} \mathrm{C}$ reached the final cell density higher than their counterpart WT/CV: about four-fold for MG1655 and W3110, and two-fold in the case of DH10B. Marginal growth improvements $(<15 \%)$ were observed for the cultures at $37^{\circ} \mathrm{C}$. All the growth curve experiments indicate that thermotolerance by ybeD-overexpression is a common effect in E. coli strains, although the extent varied with E. coli strains.

\section{Effect of $y b e D$-Overexpression in Mutants Deficient of Chaperon Genes on Bacterial Growth}

E. coli strains possess a variety of heat shock chaperones [6]. Among them, GroEL and GroES are the only molecular chaperone essential for cell growth at all temperatures [31]. To know if the growth improvement by ybeD-overexpression also occurs in the different deletion background of heat shock proteins, we transferred pybeD into single-deletion mutant of chaperone genes, which was grown and compared with the corresponding deletion background. To this end, in-frame deletion mutants of chaperone genes (dnaJ, $\operatorname{clpB}, h t p G$, and tig) were obtained from Keio collection of single-gene deletion mutants of E. coli K-12 BW25113 [30]. The gene deletions were confirmed by PCR. We attempted to grow BW25113 $\Delta$ dnaK from Keio collection, however, we failed to get a colony. Instead, we tested the mutant deficient of tig encoding trigger factor (TF) because the ribosome-associated chaperone is one of the major chaperones. TF was also reported to have partially overlapping function with DnaK, although it is not a $r p o H$ regulon member [32].

Growth of $y b e D$-overexpression in each of the deletion backgrounds was compared with those of the corresponding deletion background and Keio collection parent strain BW25113 (Fig. 4). At $37^{\circ} \mathrm{C}$, the growth levels of ybeDoverexpressing strains were comparable to those of the corresponding deletion background and the wild-type strains. At $46^{\circ} \mathrm{C}, y b e D$-overexpressing strains exhibited better growth than their deletion backgrounds, especially in the case of $\Delta d n a J$. However, the growth improvement was only the recovery level of the wild-type growth, and even $y b e D$-overexpression in $\Delta t i g$ did not make any appreciable growth improvement. Considering that ybeDoverexpression in wild-type BW25113 led to much higher growth yield (2.8-fold) than BW25113 (Fig. 3B), the growth improvements by ybeD-overexpression in deletion backgrounds of the chaperone genes were rather marginal. These might imply that YbeD interacts cooperatively with members of heat shock proteins for the thermotolerance.

\section{Effect of $y b e D$-Expression under Different Stress Conditions}

Heat shock proteins provide a fundamental protection mechanism, and they are highly induced when cells are exposed to many stressful conditions such as oxidative stress and foreign protein overexpression [33]. It was reported that the protein abundance of YbeD increased 16fold in E. coli overexpressing membrane proteins [34]. We investigated the effect of $y b e D$-expression on bacterial growth under different stress conditions of temperature, $\mathrm{pH}$, and osmolality (Fig. 5). Wild-type BL21(DE3) (WT/CV), ybeD-deletion mutant $(\Delta y b e D / C V)$, and ybeD-overexpressing strain $(\mathrm{WT} / \mathrm{pybeD})$ were grown in LB media for $24 \mathrm{~h}$, and their final cell densities were measured. The tested culture conditions were different combinations of values in temperature $\left(23^{\circ} \mathrm{C}, 37^{\circ} \mathrm{C}\right.$, and $\left.46^{\circ} \mathrm{C}\right), \mathrm{pH}(5.5,7.0$, and 8.0$)$, and osmolality $(0.17 \mathrm{M}$ and $0.5 \mathrm{M})$. Under all the tested culture conditions, $\Delta y b e D / C V$ exhibited lower final cell densities than WT/CV. WT/pybeD showed better growth only at $46^{\circ} \mathrm{C}$ than $\mathrm{WT} / \mathrm{CV}$. These observations might imply that function of $y b e D$ gene is closely related to cell growth and is especially beneficial to growth at high temperatures.

In this study, we found that ybeD-overexpression promoted cell growth at a high temperature. In wild-type E. coli BL21(DE3), ybeD was highly expressed when cells were exposed to high temperatures. At $46^{\circ} \mathrm{C}$, ybeD-deletion reduced the final cell density, while ybeD-overexpression increased the cell yield. However, at $37^{\circ} \mathrm{C}$, the $y b e \mathrm{D}$ manipulations had little effect on cell growth. Coexpression of bacterial chaperones, mainly DnaK and GroEL, have been widely used for overexpression of recombinant proteins [8]. However, overexpression of chaperones can lead to metabolic burden, often resulting in 

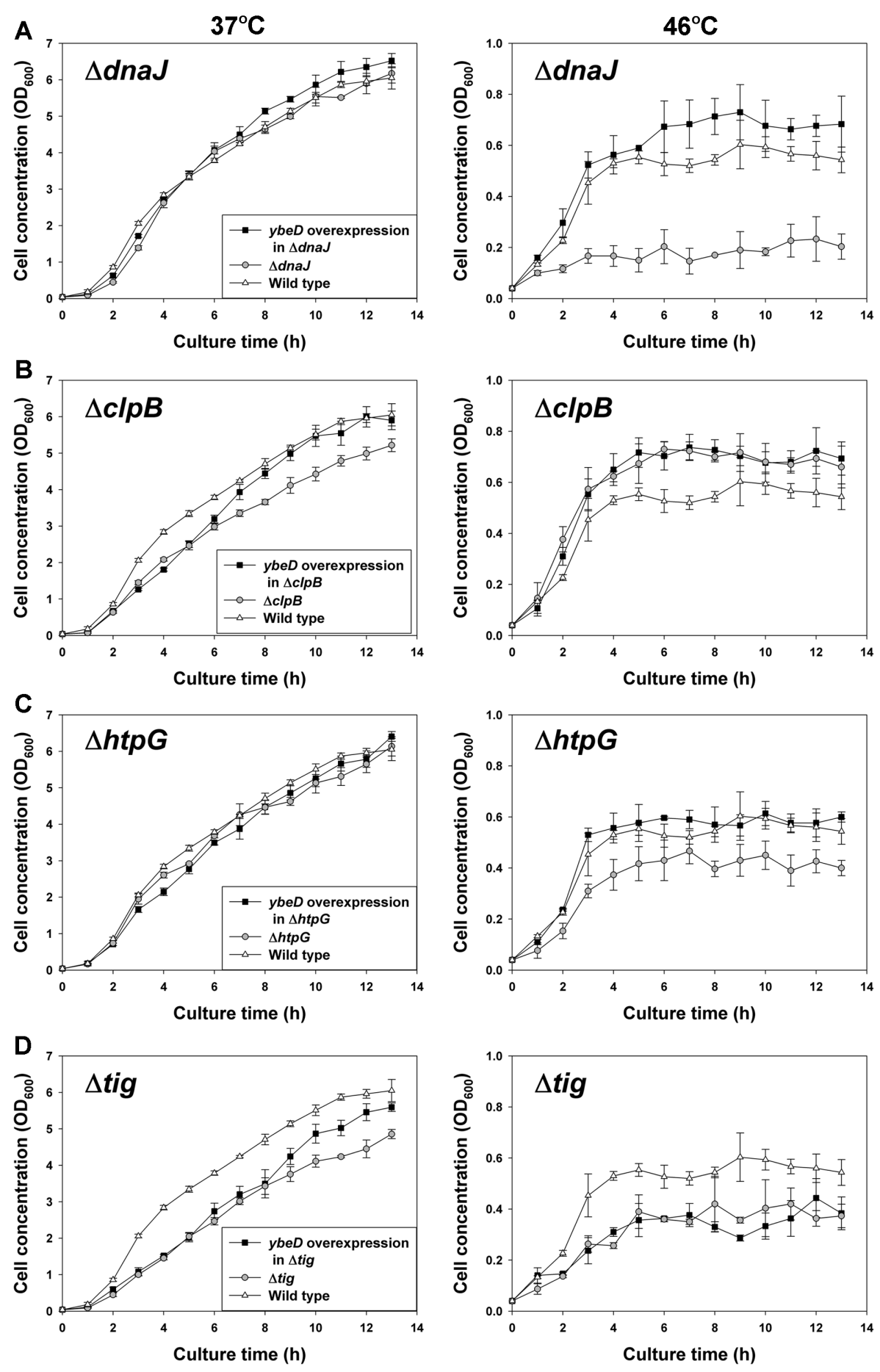

Fig. 4. Effect of $y b e D$-overexpression in deletion backgrounds of chaperone genes on bacterial growth at $37^{\circ} \mathrm{C}$ and $46^{\circ} \mathrm{C}$.

Deletion backgrounds are (A) $\Delta d n a J,(B) \Delta c l p B,(C) \Delta h t p G$, and (D) $\Delta$ tig. Shown are strains of wild-type BW25113 (WT/CV, denoted as $\triangle$ ), deletion mutant $(\Delta g e n e / C V, \bigcirc)$, and ybeD-overexpression in each deletion background $(\Delta g e n e / \mathrm{p} y b e D, \mathbf{\square})$. The error bar denotes the standard deviation of the mean from three independent cultivations.

slow cell growth and reduced cell yield [7]. Results obtained in this study reveal that $y b e D$ encodes heat shock protein whose expression is required for overcoming hightemperature stress. Thus, ybeD expression can be modulated 


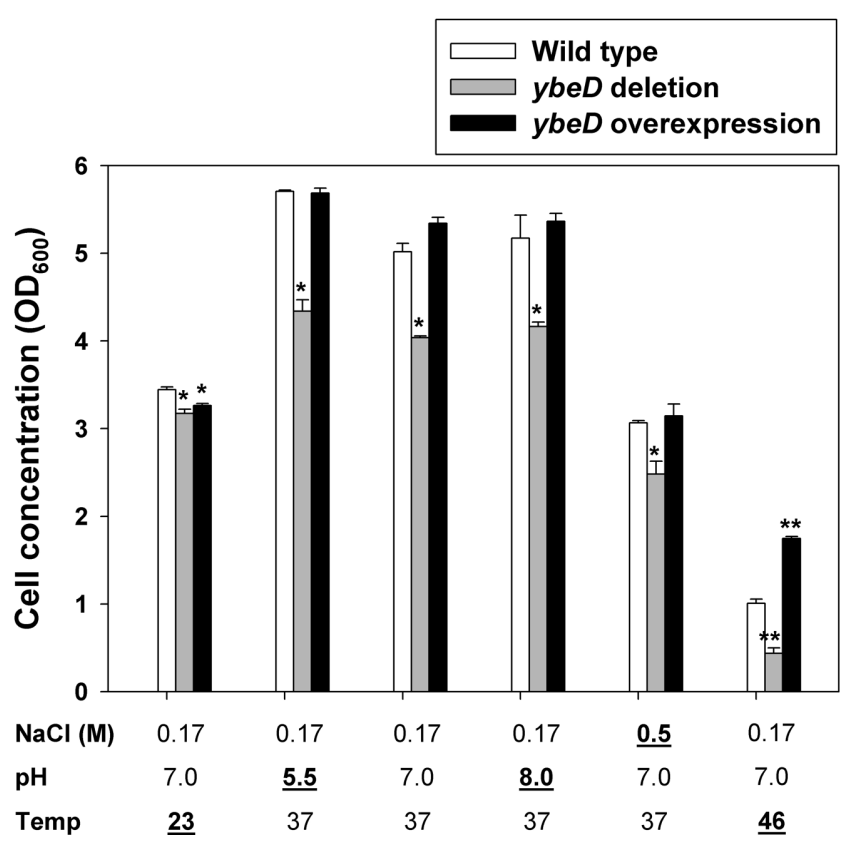

Fig. 5. Final cell densities of wild-type BL21(DE3) and its ybeD-deletion/overexpression strains under stress conditions of temperature, $\mathrm{pH}$, and osmolality.

Cells were grown for $24 \mathrm{~h}$ in LB media under different culture conditions. Different combinations of values in temperature, $\mathrm{pH}$, and osmolality are denoted under grouped bars, with high or low values underlined. The error bar denotes the standard deviation of the mean from three independent cultivations. Asterisks indicate significant difference between $y b e D$-deletion (or overexpression) strain and the wild-type strain at each culture condition $\left({ }^{*} p\right.$-value $<0.05,{ }^{* *} p$-value $<0.01)$.

to develop thermotolerant microbial hosts for industrial applications.

\section{Acknowledgments}

This paper was supported by Konkuk University in 2016.

\section{Conflict of Interest}

The authors have no financial conflicts of interest to declare.

\section{References}

1. Ezemaduka AN, Yu J, Shi X, Zhang K, Yin CC, Fu X, et al. 2014. A small heat shock protein enables Escherichia coli to grow at a lethal temperature of $50^{\circ} \mathrm{C}$ conceivably by maintaining cell envelope integrity. J. Bacteriol. 196: 2004-2011.
2. Liu D, Lu Z, Mao Z, Liu S. 2009. Enhanced thermotolerance of E. coli by expressed OsHsp90 from rice (Oryza sativa L.). Curr. Microbiol. 58: 129-133.

3. Gasser B, Saloheimo M, Rinas U, Dragosits M, RodriguezCarmona E, Baumann K, et al. 2008. Protein folding and conformational stress in microbial cells producing recombinant proteins: a host comparative overview. Microb. Cell Fact. 7: 11.

4. Zhang X, Liu Y, Genereux JC, Nolan C, Singh M, Kelly JW. 2014. Heat-shock response transcriptional program enables high-yield and high-quality recombinant protein production in Escherichia coli. ACS Chem. Biol. 9: 1945-1949.

5. Arsene F, Tomoyasu T, Bukau B. 2000. The heat shock response of Escherichia coli. Int. J. Food Microbiol. 55: 3-9.

6. Gross CA. 1996. Function and regulation of the heat shock proteins, pp. 1382-1399. In Neidhardt FC (ed.), Escherichia coli and Salmonella, Ed. ASM Press, Washington.

7. Martinez-Alonso M, Garcia-Fruitos E, Ferrer-Miralles N, Rinas U, Villaverde A. 2010. Side effects of chaperone gene co-expression in recombinant protein production. Microb. Cell Fact. 9: 64.

8. Kolaj O, Spada S, Robin S, Wall JG. 2009. Use of folding modulators to improve heterologous protein production in Escherichia coli. Microb. Cell Fact. 8: 9.

9. Nonaka G, Blankschien M, Herman C, Gross CA, Rhodius VA. 2006. Regulon and promoter analysis of the E. coli heatshock factor, $\sigma^{32}$, reveals a multifaceted cellular response to heat stress. Genes Dev. 20: 1776-1789.

10. Shimada T, Tanaka K, Ishihama A. 2017. The whole set of the constitutive promoters recognized by four minor sigma subunits of Escherichia coli RNA polymerase. PLoS One 12: e0179181.

11. Peabody MA, Laird MR, Vlasschaert C, Lo R, Brinkman FS. 2016. PSORTdb: expanding the bacteria and archaea protein subcellular localization database to better reflect diversity in cell envelope structures. Nucleic Acids Res. 44: D663-668.

12. Ishihama $Y$, Schmidt T, Rappsilber J, Mann M, Hartl FU, Kerner MJ, et al. 2008. Protein abundance profiling of the Escherichia coli cytosol. BMC Genomics 9: 102.

13. Kozlov G, Elias D, Semesi A, Yee A, Cygler M, Gehring K. 2004. Structural similarity of YbeD protein from Escherichia coli to allosteric regulatory domains. J. Bacteriol. 186: 8083-8088.

14. Yoon SH, Jeong H, Kwon S-K, Kim JF. 2009. Genomics, biological features, and biotechnological applications of Escherichia coli B: "Is B for better?!", pp. 1-17. Systems Biology and Biotechnology of Escherichia coli, Ed. Springer, Berlin, Germany

15. Choi JH, Keum KC, Lee SY. 2006. Production of recombinant proteins by high cell density culture of Escherichia coli Chem. Eng. Sci. 61: 876-885.

16. Studier FW, Moffatt BA. 1986. Use of bacteriophage T7 RNA polymerase to direct selective high-level expression of cloned genes. J. Mol. Biol. 189: 113-130. 
17. Datsenko KA, Wanner BL. 2000. One-step inactivation of chromosomal genes in Escherichia coli K-12 using PCR products. Proc. Natl. Acad. Sci. USA 97: 6640-6645.

18. Kim SK, Lee DH, Kim OC, Kim JF, Yoon SH. 2017. Tunable control of an Escherichia coli expression system for the overproduction of membrane proteins by titrated expression of a mutant lac repressor. ACS Synth. Biol. 6: 1766-1773.

19. Kim S, Jeong H, Kim EY, Kim JF, Lee SY, Yoon SH. 2017. Genomic and transcriptomic landscape of Escherichia coli BL21(DE3). Nucleic Acids Res. 45: 5285-5293.

20. Livak KJ, Schmittgen TD. 2001. Analysis of relative gene expression data using real-time quantitative PCR and the $2_{\mathrm{T}}^{-\Delta \Lambda \mathrm{C}}$ Method. Methods 25: 402-408.

21. Schagger H. 2006. Tricine-SDS-PAGE. Nat. Protoc. 1: 16-22.

22. Chen IA, Markowitz VM, Chu K, Palaniappan K, Szeto E, Pillay $\mathrm{M}$, et al. 2017. IMG/M: integrated genome and metagenome comparative data analysis system. Nucleic Acids Res. 45: D507-d516.

23. Durfee T, Nelson R, Baldwin S, Plunkett G, 3rd, Burland V, Mau B, et al. 2008. The complete genome sequence of Escherichia coli DH10B: insights into the biology of a laboratory workhorse. J. Bacteriol. 190: 2597-2606.

24. Bukau B, Walker GC. 1989. Cellular defects caused by deletion of the Escherichia coli dnaK gene indicate roles for heat shock protein in normal metabolism. J. Bacteriol. 171: 2337-2346.

25. Teleha MA, Miller AC, Larsen RA. 2013. Overexpression of the Escherichia coli TolQ protein leads to a null-FtsN-like division phenotype. Microbiologyopen 2: 618-632.

26. Herendeen SL, VanBogelen RA, Neidhardt FC. 1979. Levels of major proteins of Escherichia coli during growth at different temperatures. J. Bacteriol. 139: 185-194.
27. Ron EZ, Davis BD. 1971. Growth rate of Escherichia coli at elevated temperatures: limitation by methionine. J. Bacteriol. 107: 391-396.

28. Ron EZ, Shani M. 1971. Growth rate of Escherichia coli at elevated temperatures: reversible inhibition of homoserine trans-succinylase. J. Bacteriol. 107: 397-400.

29. Jordan SW, Cronan JE, Jr. 2003. The Escherichia coli lipB gene encodes lipoyl (octanoyl)-acyl carrier protein:protein transferase. J. Bacteriol. 185: 1582-1589.

30. Baba T, Ara T, Hasegawa M, Takai Y, Okumura Y, Baba M, et al. 2006. Construction of Escherichia coli K-12 in-frame, single-gene knockout mutants: the Keio collection. Mol. Syst. Biol. 2: 20060008.

31. Fayet O, Ziegelhoffer T, Georgopoulos C. 1989. The groES and groEL heat shock gene products of Escherichia coli are essential for bacterial growth at all temperatures. J. Bacteriol. 171: 1379-1385.

32. Teter SA, Houry WA, Ang D, Tradler T, Rockabrand D, Fischer G, et al. 1999. Polypeptide flux through bacterial Hsp70: DnaK cooperates with trigger factor in chaperoning nascent chains. Cell 97: 755-765.

33. Wick LM, Egli T. 2004. Molecular components of physiological stress responses in Escherichia coli. Adv. Biochem. Eng. Biotechnol. 89: 1-45.

34. Wagner S, Baars L, Ytterberg AJ, Klussmeier A, Wagner CS, Nord O, et al. 2007. Consequences of membrane protein overexpression in Escherichia coli. Mol. Cell. Proteomics 6: 1527-1550. 